\title{
Study of Deterioration of the Quality of Gasoil adultération with Kerosene: A Case of Smuggling Activities at the YEMA Border in DRC
}

\author{
Yondo ngandu Vially \\ Faculty of Oil, Gas and Renewable energy \\ University of Kinshasa, DR Congo
}

\begin{abstract}
Several professional laboratories are actively concerned with the issue of the compliant certification of smuggled fuels from the Angolan borders of YEMA, YACHT, KUNGU, LUFU and others with regard to the quality standards and specifications in force in the Democratic Republic of the Congo. Despite the rigor of the standards and quality specifications in force, the physicochemical characterization of gasoil-kerosene mixtures resulting from smuggling activities (adulterated gasoil), remains a subject little explored and sometimes subjective with regard to the standards. In fact, the standards define the means and methods to be used to test the quality of a fuel, and the specifications impose the characteristics that this fuel must meet. the specifications require for each physicochemical parameter (density, viscosity, flash point, cetane number, distillation, etc.) a range of values beyond which the product is declared non-compliant. in the laboratory, a diesel fuel is said to be compliant when all the physicochemical parameters analyzed according to the recommended standards are within the range of values required by the specifications in force. however, the results obtained during this study inform us that the reporting conforming to the standards of a Gasoil suspected of smuggling should not be limited simply by observing the specifications. in fact, we have carried out analytical tests in the laboratory (density, sulfur content, viscosity, color, distillation and flash point) on gasoline-kerosene weight mixtures thus simulating a practice of smuggling Gasoil which is the dilution of Kerosene. thus, we believe that a comprehensive analysis of this fuel should include.
\end{abstract}

- Compliance with standards and specifications of all physicochemical characteristics.

- Interpretation of the ASTM distillation curve

- Critical analysis of the values of each of the physicochemical characteristics of volatility alongside others (Flash Point, Initial Distillation Point, Recovery 50\%, Recovery 65\%) because they are all linked by a logic.

Keywords: Deterioration, Flash Point, Physicochemical Characteristics, Turbidity.

\section{INTRODUCTION}

the uses of petroleum products are extremely numerous such that spark ignition engines, diesel engines or aircraft turbines require fuels which, even if they are derived from crude petroleum, have different physicochemical characteristics [1].

Gasoil is a fuel intended for supplying diesel engines in several types of vehicles. Therefore, all the properties required of diesel are justified by the specifications of the Diesel cycle:

- The mode of Introduction

- The process of initiation and course of combustion

- The power adjustment mode

The diesel engine sucks in and compresses clean air, while the fuel injected into the cylinder in spray form at the end of compression vaporizes in the air. Ignition arises by self-ignition in one or more areas of the combustion chamber where the temperature, pressure and concentration conditions necessary to initiate combustion are met. [2]. 
diesel fuel must therefore exhibit a strong tendency towards self-ignition since the operating principle of the diesel engine is based on the ignition of fuel injected under high pressure into the air, previously compressed. this diesel quality is expressed by the cetane number which, unlike the octane number, does not directly influence the performance of the engine but rather acts on the ease of use (cold start, noises, emission of pollutants). another essential characteristic of diesel fuel is its resistance to cold since the formation of paraffin crystals within it at low temperatures could clog the filter placed on the supply circuit. the refiner adjusts the cetane number and the cold characteristics of the diesel by acting on the nature and composition of the constituent bases and by incorporating certain additives. to promote self-ignition, especially under marginal conditions of use (cold start for example) it is necessary to adopt a high compression ratio. this feature and other purely thermodynamic considerations (specific heat of the gases present in the cylinder) explain the fact that the diesel engine generally has very good efficiency. the power is adjusted by adjusting the flow rate of diesel introduced into a fixed volume of air[3].

in addition, the need to perform high pressure injection and fine droplet spraying by means of an injector imposes very precise volatility characteristics for diesel fuel. the European specifications set two criteria defining a minimum and maximum volatility. [4] Thus the distilled fraction (\% volume) must be:

- $\quad$ Less than $65 \%$ for a temperature of $250^{\circ} \mathrm{C}$

- Greater than $85 \%$ for a temperature of $350{ }^{\circ} \mathrm{C}$

- Greater than $95 \%$ for a temperature of $370{ }^{\circ} \mathrm{C}$

the density, the distillation curve, the viscosity and the behavior at low temperature constitute the essential characteristics of the diesel fuel necessary for the satisfactory operation of the engine. To this should be added the sulfur content, cetane number and total acidity.

\section{MATERIALS AND METHODS}

\subsection{Sampling}

Yema is a Congolese-Angolan land border that the DRC through the territory of Moanda in the province of Kongo central shares with the Angolan province of Cabinda. located at $5^{\circ} 55^{\prime} 48$ "S and $12^{\circ} 21^{\prime} 00^{\prime \prime} \mathrm{E}$, the territory of Moanda includes the port of Banana 15 kilometers to the south. In this territory, fuel trafficking occurs between these two countries, sometimes without any rigorous control. cargoes of fuels (diesel, gasoline) and combustibles (Kerosene) cross the Congolese border in hermetically sealed plastic drums. during our sampling campaign, we were unable to sample all the barrels entering the DRC following the refusal of traders and traffickers. however, we have carried out systematic batch sampling as this represents a set of drums containing the same product.

A total of 20 samples were taken including:

- 15 samples of 1 Liter each from the same batch of diesel contained in different plastic drums

- 5 samples of 1 liter each of kerosene from the same lot of kerosene contained in different drums

from all these samples, we made 2 representative samples:

- 5 liters for Diesel

- 3 liters of kerosene

\subsection{METHODS}

\subsubsection{Preparation of samples}

To simulate the practice of dilution of Gasoil by kerosene in the laboratory as performed during smuggling activities, we performed weight dilutions of Gasoil by kerosene:

$\varphi_{\mathrm{g}}:$ Gasoil volume fraction $\left(0 \leq \varphi_{\mathrm{g}} \leq 1\right)$

$\varphi_{\mathrm{k}}$ : Kerosene volume fraction $\left(0 \leq \varphi_{\mathrm{k}} \leq 1\right)$

$$
\sum_{j=1}^{2} \varphi \mathrm{j}=1
$$


International Journal of Advances in Scientific Research and Engineering (ijasre), Vol 6 (12), December -2020 Thus,

\begin{tabular}{|l|l|l|l|}
\hline$\varphi_{\mathrm{g}}$ & $\varphi_{\mathrm{k}}$ & $\%$ & Sample Name \\
\hline 1 & 0 & 0 & $\mathrm{G} 0$ \\
\hline 0,9 & 0,1 & 10 & $\mathrm{G} 10$ \\
\hline 0,8 & 0,2 & 20 & $\mathrm{G} 20$ \\
\hline 0,7 & 0,3 & 30 & $\mathrm{G} 30$ \\
\hline 0,6 & 0,4 & 40 & $\mathrm{G} 40$ \\
\hline 0,5 & 0,5 & 50 & $\mathrm{G} 50$ \\
\hline
\end{tabular}

With :

- G0 : Binairy mixture consisting of $0 \%$ Kerosene and $100 \%$ Gasoil

- G10 : Binairy mixture consisting of $10 \%$ Kerosene and $90 \%$ Gasoil

- G20 Binairy mixture consisting of $20 \%$ Kerosene and $80 \%$ Gasoil

- G40 : Binairy mixture consisting of 30\% Kerosene and $70 \%$ Gasoil

- G40 : Binairy mixture consisting of $40 \%$ Kerosene and $60 \%$ Gasoil

- G50 : Binairy mixture consisting of 50\% Kerosene and 50\% Gasoil

\subsubsection{Materials}

Thermo densimeter model TOLEDO METTLER conforming to ASTM D4072

$>$ Colorimeter model PETROLEUM OILS COMPARATOR conforming to ASTM D1500

$>$ Flash Point Instrument model PENSKY MARTENS conforming to ASTM D93

$>$ Kinematic viscometer model Canon Fenske and silicone Oil bath conforming to ASTM D445

$>$ X-ray Spectrometer Epsillon 1 conforming to ASTM D 4294

$>$ Automatic Still conforming to ASTM D 86 
International Journal of Advances in Scientific Research and Engineering (ijasre), Vol 6 (12), December -2020

\subsubsection{Analyse}

The laboratory analyzes were carried out in accordance with Ministerial Decree N $^{\circ} 001 / \mathrm{MIN}-\mathrm{HYD} / \mathrm{CATM} / \mathrm{CAB} / \mathrm{MIN} / 2015$ of $14 / 02 / 2015$ setting the standards and specifications for fuel analysis in force in the DRC

Table 1 : Gasoil Standards and specifications in force in DRC

\begin{tabular}{|c|c|c|c|}
\hline TEST & METHOD & UNITES & RESULT \\
\hline$\overline{\text { ASPECT }}$ & & & Clear and limpid \\
\hline TURBIDITY & ASTM D 4176 & & $<2$ \\
\hline & ASTM D 1298 & & \\
\hline DENSITY@ $15^{\circ} \mathrm{C}$ & ASTM D 4052 & $\mathrm{Kg} / \mathrm{l}$ & $0.8200-0.8800$ \\
\hline COLOUR & ASTM D 1500 & & 3.5 Max \\
\hline FLASH POINT & ASTM D 93 & ${ }^{\circ} \mathrm{C}$ & 60Min \\
\hline $\begin{array}{l}\text { KIN VISCOSITY@ } \\
37,8^{\circ} \mathrm{C}\end{array}$ & ASTM D 445 & CSt & 2.0Min/6.0 Max \\
\hline $\begin{array}{l}\text { CU.C } \\
\text { 3HRS@100 }{ }^{\circ} \mathrm{C}\end{array}$ & ASTM D 130 & Code & 1b Max \\
\hline DISTILLATION & ASTM D 86 & & \\
\hline $\begin{array}{l}\text { RECOVERY @ } \\
360^{\circ} \mathrm{C}\end{array}$ & & $\%$ vol & 90.0 Min \\
\hline POUR POINT & ASTM D 97 & ${ }^{\circ} \mathrm{C}$ & +6 Max \\
\hline TOTAL SULPHUR & ASTM D 4294 & $\%$ pds & $0.05 \mathrm{Max}$ \\
\hline $\begin{array}{l}\text { CARBON } \\
\text { RESIDUE 10\% }\end{array}$ & ASTM D 189 & $\%$ pds & 0.15 Max \\
\hline $\begin{array}{l}\text { SEDIMENT BY } \\
\text { EXT }\end{array}$ & ASTM D 473 & $\%$ pds & 0.01 Max \\
\hline ASH CONTENT & ASTM D 482 & $\%$ pds & 0.01 Max \\
\hline $\begin{array}{l}\text { WATER } \\
\text { CONTENT }\end{array}$ & ASTM D 95 & $\%$ vol & $0.05 \mathrm{Max}$ \\
\hline TOTAL ACIDITY & ASTM D 974 & $\begin{array}{l}\mathrm{Mg} \\
\mathrm{KOH} / \mathrm{g}\end{array}$ & $0.5 \mathrm{Max}$ \\
\hline $\begin{array}{l}\text { STRONG ACID } \\
\text { NUMBER }\end{array}$ & ASTM D 974 & $\begin{array}{l}\mathrm{Mg} \\
\mathrm{KOH} / \mathrm{g}\end{array}$ & Nulle \\
\hline CETANE INDEX & ASTM D 976 & & 45,0 Min \\
\hline FAME & ASTM D 7371 & & Not detectable \\
\hline
\end{tabular}

\section{RESULTS AND DISCUSSION}

3.1. Results

Table.2: Results Analysis

\begin{tabular}{|l|l|l|l|l|l|l|l|l|l|}
\hline \multicolumn{1}{|c|}{ TEST } & \multicolumn{1}{|c|}{ METHOD } & UNIT & STANDARDS & G0 & G10 & G20 & G30 & G40 & G50 \\
\hline DENSITY @ 15 ${ }^{\circ} \mathrm{C}$ & ASTM D 4052 & Kg/l & $0.82-0.88$ & 0.8417 & 0.837 & 0.8325 & 0.8285 & 0.8217 & 0.8175 \\
\hline COLOUR & ASTM D 1500 & & $3.5 \mathrm{Max}$ & $\mathrm{L} 3$ & $\mathrm{~L} 2.5$ & $\mathrm{~L} 2$ & $\mathrm{~L} 2$ & $\mathrm{~L} 2$ & $\mathrm{~L} 1.5$ \\
\hline KIN VISCO @37,8 ${ }^{\circ} \mathrm{C}$ & ASTM D 445 & $\mathrm{cSt}$ & $2.0-6.0$ & 3.577 & 3.15 & 2.89 & 2.576 & 2.344 & 2.083 \\
\hline TOTAL SULPHUR & ASTM D 4294 & $\mathrm{wt} \%$ & $0.05 \mathrm{Max}$ & 0.0622 & 0.0593 & 0.0575 & 0.0502 & 0.0317 & 0.0279 \\
\hline CETANE INDEX & ASTM D 976 & & $45.0 \mathrm{Min}$ & 52 & 51 & 45 & 44 & 43.1 & 39.7 \\
\hline FLASH POINT & ASTM D 93 & ${ }^{\circ} \mathrm{C}$ & $60 \mathrm{Min}$ & 68 & 64 & 61 & 60 & 58 & 57 \\
\hline DISTILLATION & ASTM D86 & & Report & & & & & & \\
\hline RECOVERY @ 10\% & ASTM D86 & ${ }^{\circ} \mathrm{C}$ & Report & 205 & 186 & 172 & 173 & 169 & 162 \\
\hline RECOVERY @ 20\% & ASTM D86 & ${ }^{\circ} \mathrm{C}$ & Report & 232 & 209 & 191 & 189 & 184 & 179 \\
\hline RECOVERY @ 30\% & ASTM D86 & ${ }^{\circ} \mathrm{C}$ & Report & 245 & 226 & 207 & 204 & 194 & 188 \\
\hline RECOVERY @ 40\% & ASTM D86 & ${ }^{\circ} \mathrm{C}$ & Report & 263 & 250 & 224 & 217 & 207 & 198 \\
\hline RECOVERY @ 50\% & ASTM D86 & ${ }^{\circ} \mathrm{C}$ & Report & 277 & 264 & 236 & 228 & 218 & 205 \\
\hline
\end{tabular}


International Journal of Advances in Scientific Research and Engineering (ijasre), Vol 6 (12), December -2020

\begin{tabular}{|l|l|l|l|l|l|l|l|l|l|}
\hline RECOVERY @ 60\% & ASTM D86 & ${ }^{\circ} \mathrm{C}$ & Report & 294 & 285 & 263 & 252 & 244 & 233 \\
\hline RECOVERY @ 65\% & ASTM D86 & ${ }^{\circ} \mathrm{C}$ & Report & 303 & 292 & 270 & 259 & 250 & 245 \\
\hline RECOVERY @ 70\% & ASTM D86 & ${ }^{\circ} \mathrm{C}$ & Report & 310 & 304 & 281 & 274 & 270 & 258 \\
\hline RECOVERY @ 80\% & ASTM D86 & ${ }^{\circ} \mathrm{C}$ & Report & 323 & 319 & 298 & 291 & 292 & 289 \\
\hline RECOVERY @ 90\% & ASTM D86 & ${ }^{\circ} \mathrm{C}$ & Report & 344 & 339 & 317 & 312 & 317 & 320 \\
\hline RECOVERY @ 95\% & ASTM D86 & ${ }^{\circ} \mathrm{C}$ & Report & 347 & 351 & 331 & 333 & 334 & 329 \\
\hline FINAL POINT & ASTM D86 & ${ }^{\circ} \mathrm{C}$ & Report & 350 & 354 & 339 & 335 & 341 & 330 \\
\hline
\end{tabular}

The previous table presents the set of analysis results obtained, the method used as well as the unit system chosen in accordance with the fuel standards and specifications in force in the DRC. Results that deviate from the standards are written in red.

while knowing that these results are strongly linked to the initial physicochemical characteristics of G0, it is noticeable:

> The density decreases in proportion to the addition of kerosene in the mixture until reaching non-standard values for G50. indeed, the imposition of a minimum value of density is justified by the desire to obtain sufficient maximum power for the engine, by means of an injection pump whose flow rate is adjusted by volume. moreover, setting a maximum value for the density is justified by the concern to avoid the formation of fumes at full load which would be due to an increase in average richness. In this context, G50 is a dangerous fuel for the engine. in the case of a G0 with a density lower than this, the standard would already be exceeded before $50 \%$ kerosene

$>$ While remaining within the standards for all mixtures (G0, G10, G20, G30, G40 and G50), the viscosity alone cannot lead to the declaration in conformity with the standards and specifications of a diesel fuel although it is an essential property of Diesel fuel. viscosity is defined as resistance to flow. It must be between the precise limits. Indeed, a fuel that is too viscous would increase the pressure drops in the pump and the injectors, which would tend to reduce the injection pressure, deteriorate the fineness of the spray and ultimately affect the combustion process

The calculated cetane number drops in proportion to the addition of kerosene until reaching non-standard values for the G30, G40 and G50. Gasoil must therefore exhibit a strong tendency towards self-ignition since the operating principle of the diesel engine is based on the ignition of fuel injected under high pressure into the air, previously compressed. this diesel quality is expressed by the cetane number which, unlike the octane number, does not directly influence the performance of the engine but rather acts on the ease of use (cold start, noises, emission of pollutants).

For G30, G40 and G50, volatility characteristics including Flash Point and 65\% distillation point are problematic

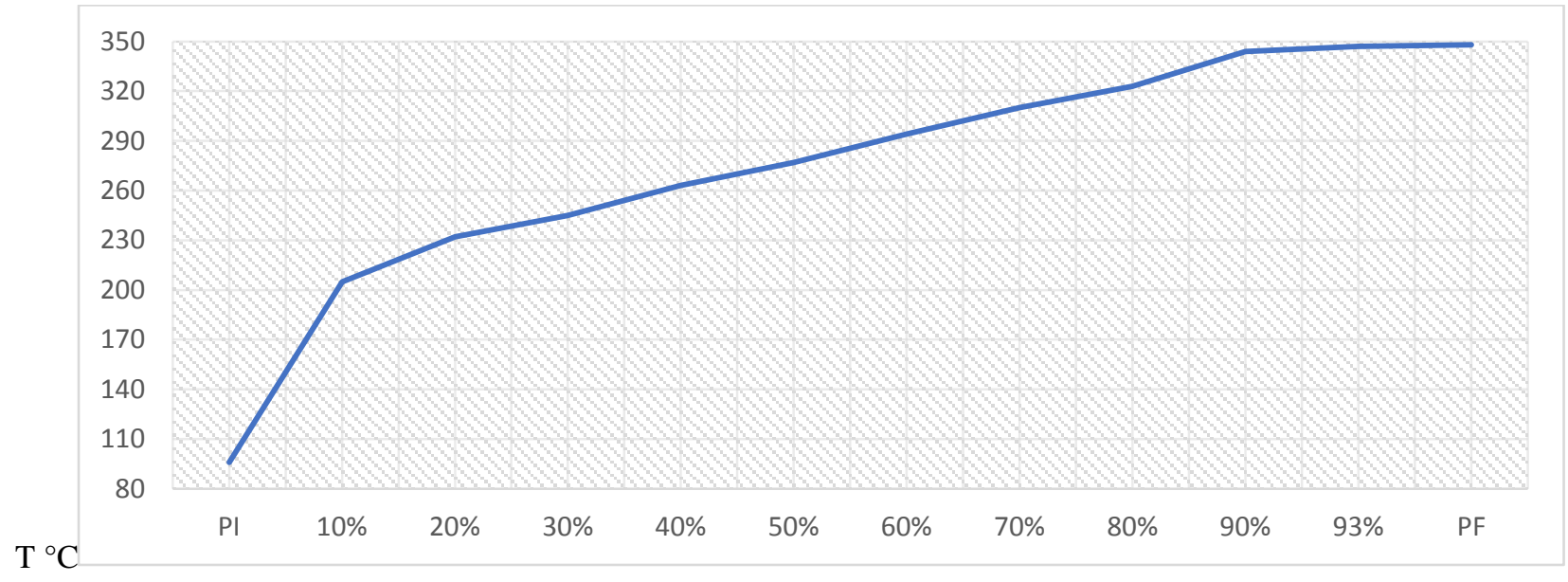

Figure 1 : Distillation Curve of G0 
International Journal of Advances in Scientific Research and Engineering (ijasre), Vol 6 (12), December -2020

$\mathrm{T}^{\circ} \mathrm{C}$

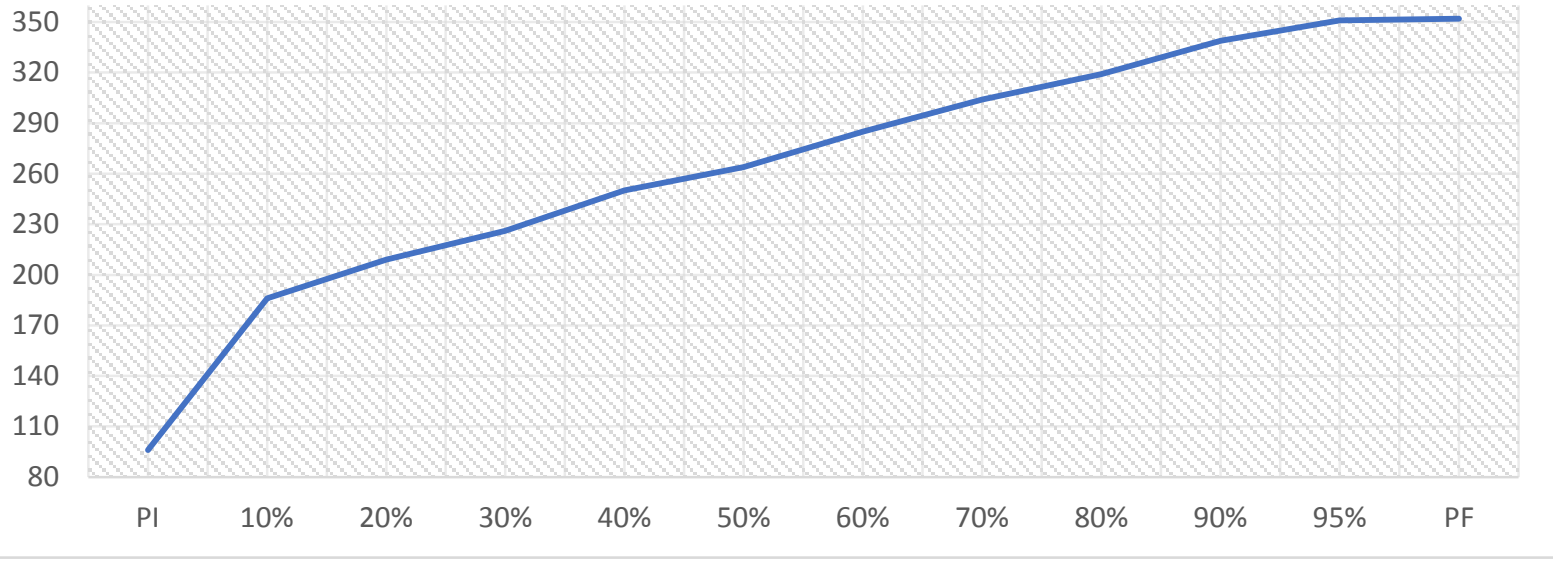

Figure 2 : Distillation Curve of G10

$\mathrm{T}^{\circ} \mathrm{C}$

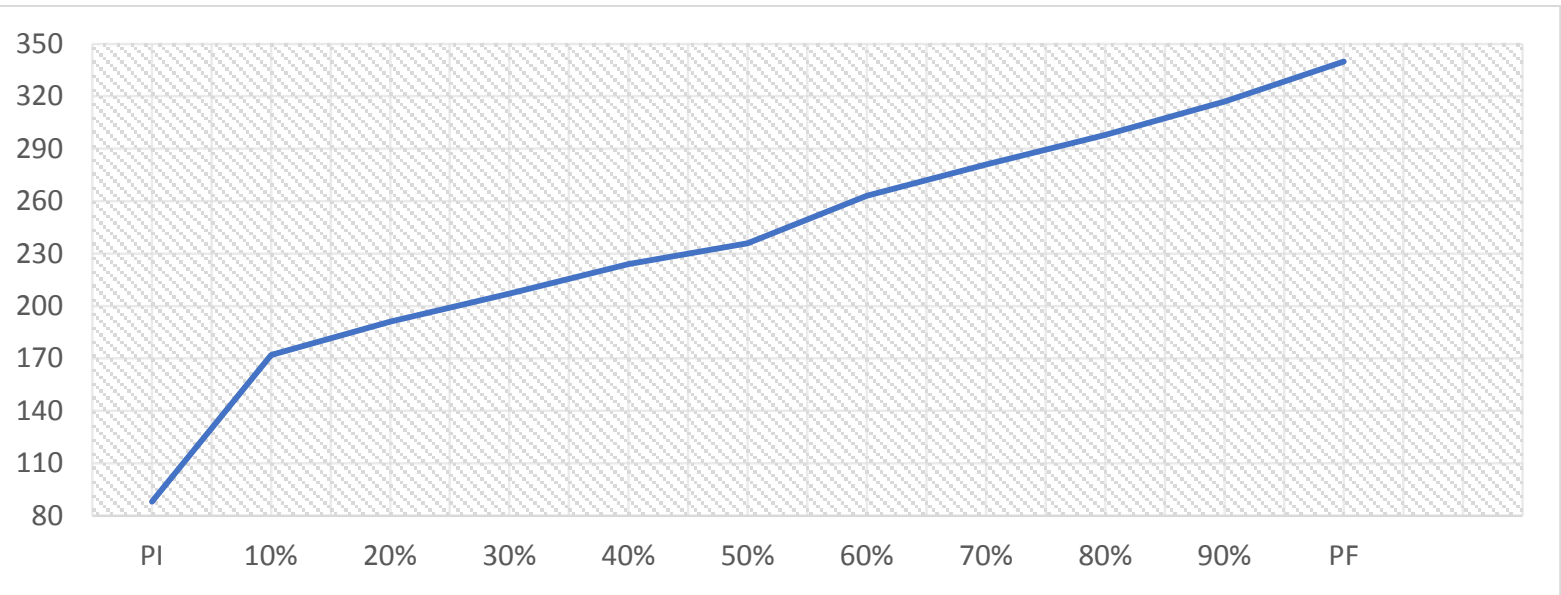

Figure 3 : Distillation Curve of G20

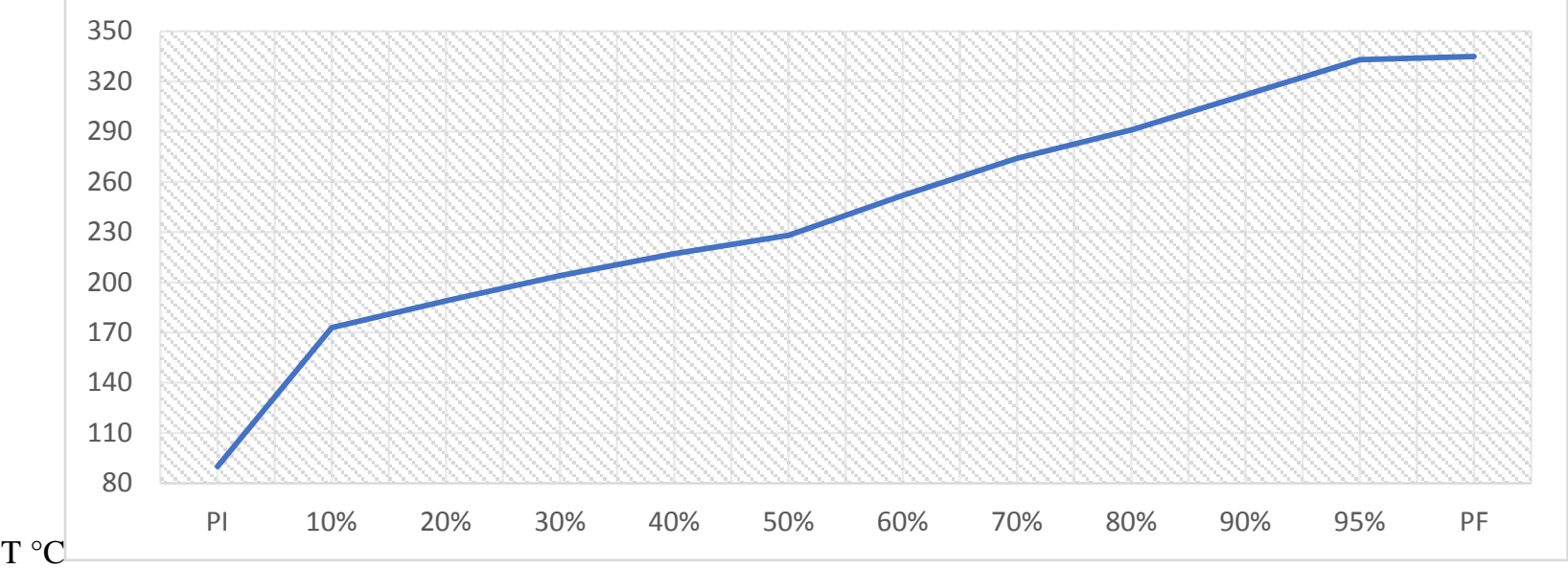

Figure 4 : Distillation Curve of G30 
International Journal of Advances in Scientific Research and Engineering (ijasre), Vol 6 (12), December -2020

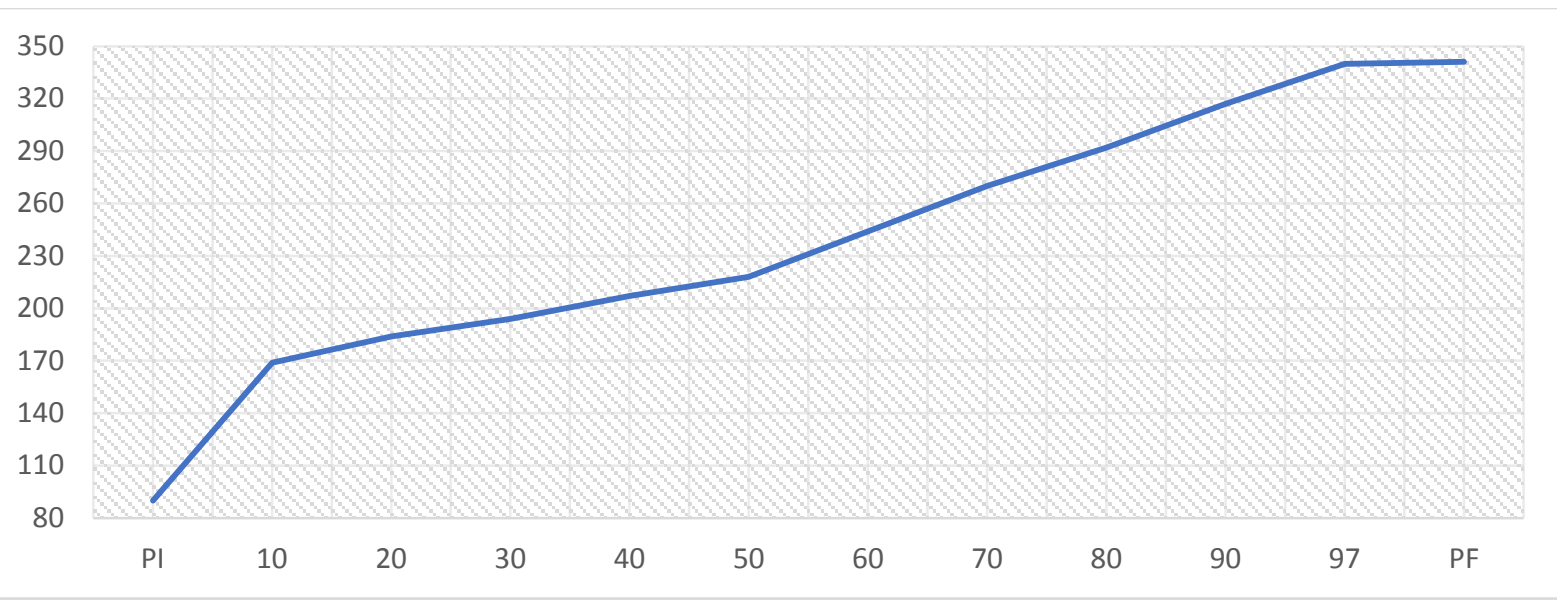

Figure 5 : Distillation Curve of G40

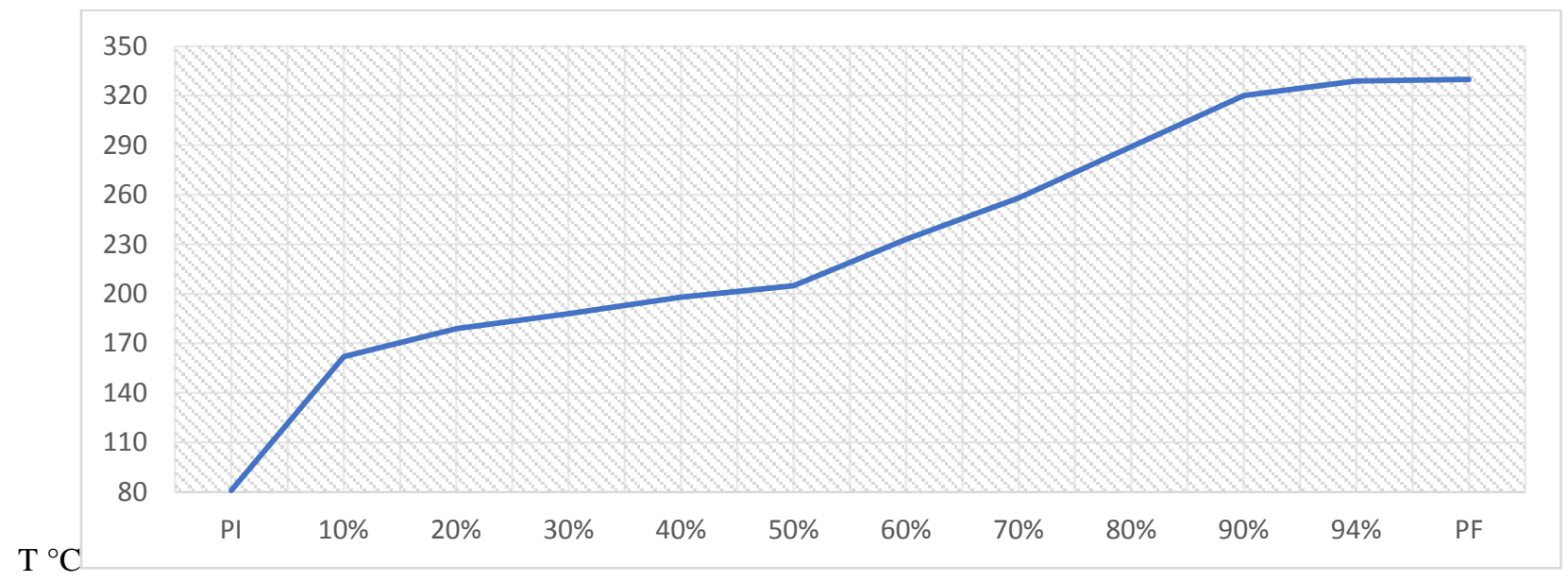

Figure 6 : Distillation Curve of G50

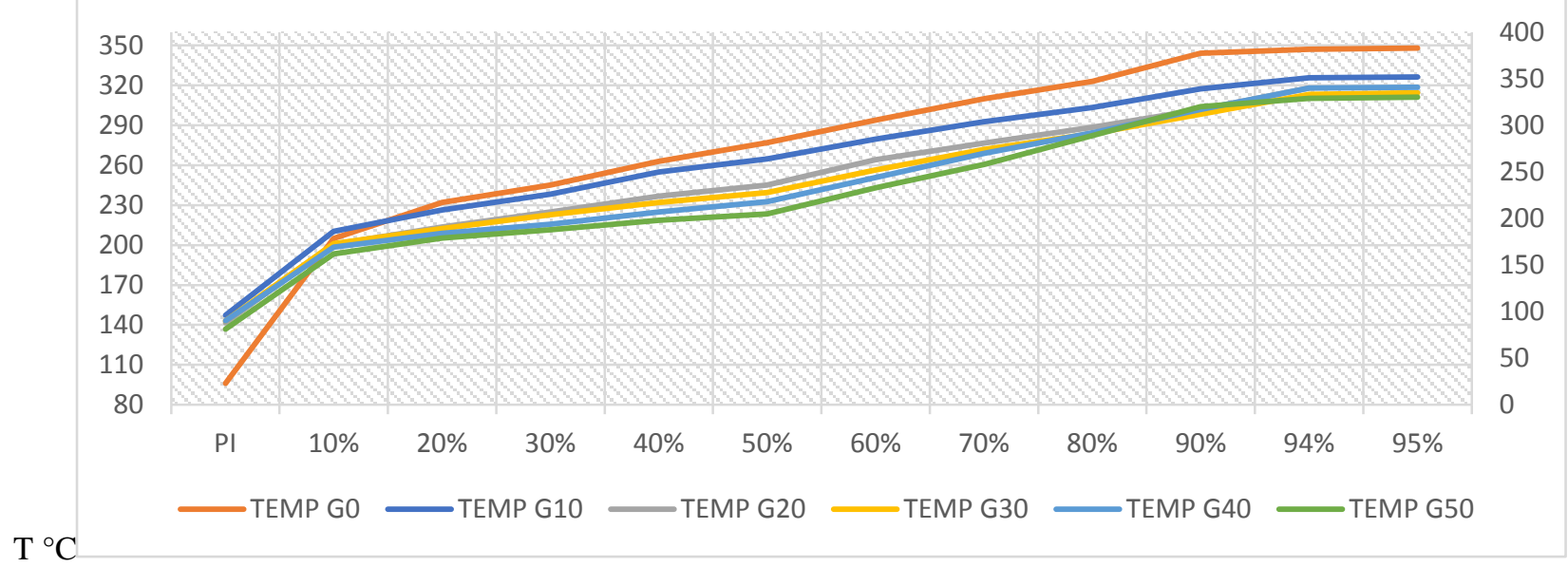

Figure 7 : All Distiilation Curves 
International Journal of Advances in Scientific Research and Engineering (ijasre), Vol 6 (12), December -2020

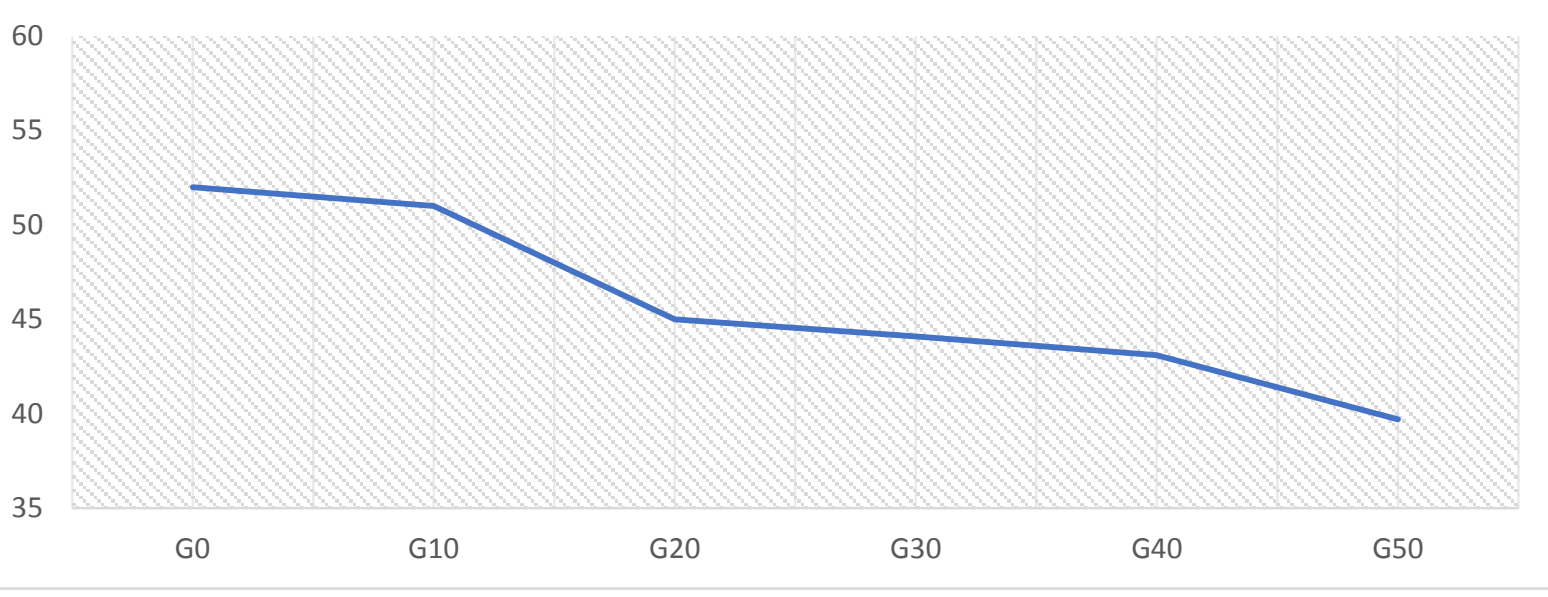

Figure 8 : Variation of the Calculated cetane Number

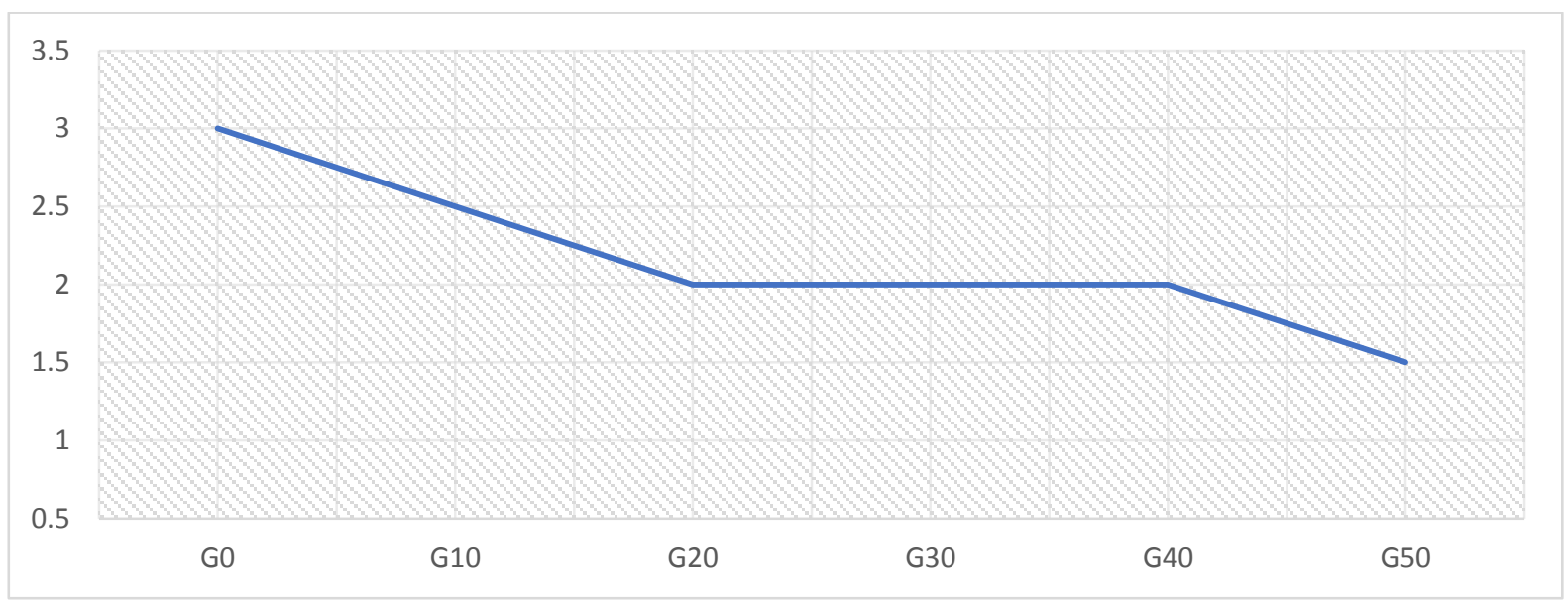

Figure 9 : Variation of the Colour ASTM

$\operatorname{PE}\left({ }^{\circ} \mathrm{C}\right)$

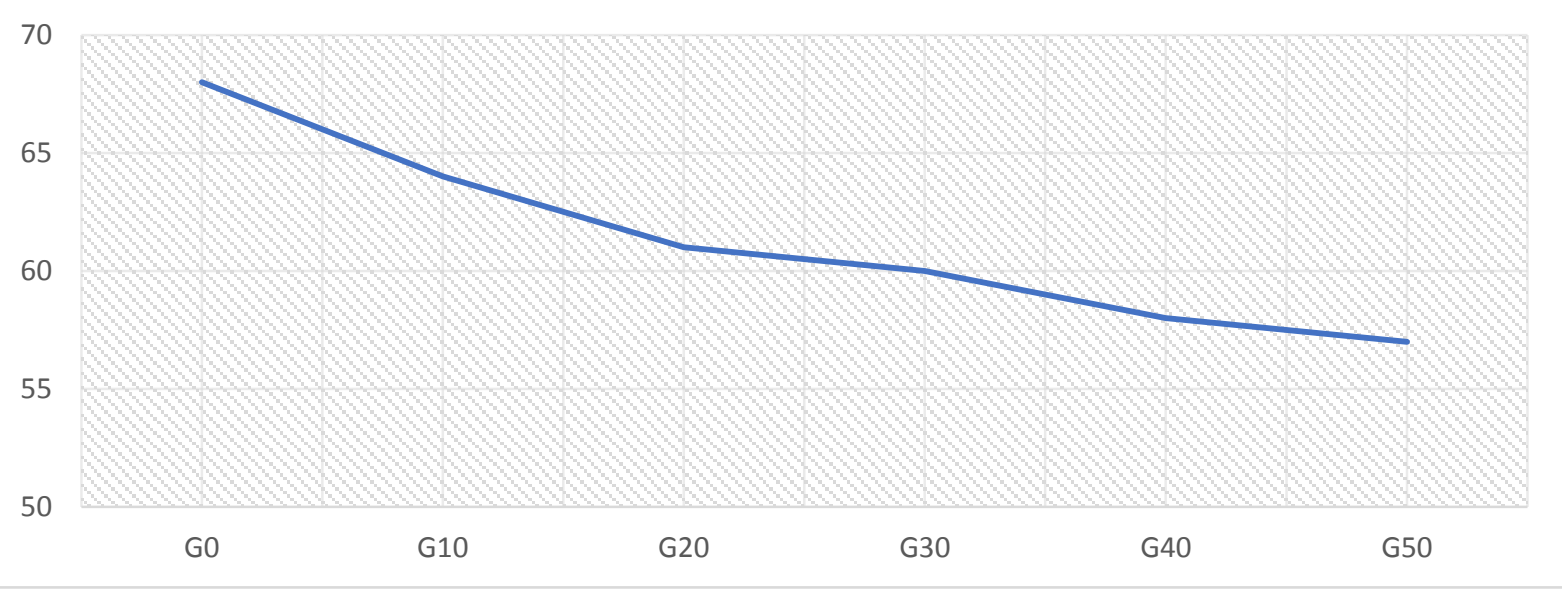

Figure 10 : Flash Point Variation

Figure.7 shows the translation of the distillation curves towards the $\mathrm{x}$-axis as the proportion of kerosene increases in the mixture. In fact, gasoil is a petroleum cut taken just after the kerosene cut in the Primary Crude Oil distillation column 
(Topping). Consequently, the addition of kerosene in the diesel increases the proportion of core fraction (Recovery $40 \%$, $50 \%, 60 \%$...) of the latter, thus making it lighter. We also observe the discontinuity (increase in slope) of the distillation curve at the core fraction level (Recovery $40 \%, 50 \%, 60 \% \ldots)$ as the proportion of kerosene increases in the mixture.

$>$ The Calculated Cetane Number, The Color, The Flash Point and even the viscosity of the Gasoil fall proportionally following the gradual addition of kerosene until reaching non-standard values.

\section{CONCLUSION}

The dilution of Gasoil by Kerosene is a practice of oil smuggling long used by traffickers to evade certain taxes. However, the adulterated Gasoil thus obtained is likely to cause incalculable and unforeseeable consequences to the Engine. In this study, we have shown the quality criteria of Gasoil which deteriorates following the weight additions of kerosene. As a conclusion we retain:

$>$ Just because a tampered gasoil has an ASTM color, density or viscosity within standards does not mean that it should be considered to meet consumer standards. In fact, the declaration of conformity with the standards and quality specifications in force is made strictly for all the physicochemical characteristics included in the standard

$>$ The observation of a discontinuity marked by the variation of the slope in the distillation curve of a Gasoil associated with a proportionally low cetane number with the Flash Point, can be a revealing index of a possible dilution of Gasoil by the Kerosene.

$>$ although it depends on the physicochemical properties of G0, any addition of kerosene in the Gasoil causes a proportional deterioration of the quality of the latter

therefore, we want rigorous control procedures to be put in place at the YEMA border post to limit these smuggling practices in order to preserve consumer rights.

\section{BIBLIOGRAPHIE}

1. Guibet, J.C, ET B.Martin (1987), Carburants et Moteurs. Editions Technip, Paris.

2. J.P WAUQUIER, Pétrole brut produits pétroliers et schemas de fabrication, IFP, technip, 1994

3. Glavincevski, B., O.L., Gulder et L.Gardner (1984), Cetane number estimation of diesel fuels from carbon typoe structural composition. SAE paper ${ }^{\circ} 84-1341$, International fuels and lubricants meeting, Baltimore, MD.

4. Wuithier, P. (1965), Le pétrole, Raffinage et Génie Chimique. Editions Technip, Paris.

5. ARRETE MINISTERIEL Nº01/MIN-HYD/CATM/CAB/MIN/2015 DU 14 /02/2015 FIXANT LES NORMES ET SPECIFICATIONS D’ANALYSE DES CARBURANTS EN VIGUEUR EN RDC

6. American Society for Testing and Materials. Standard specification for automotive gasoline: 1983 annual book of ASTM standards. (1983).

7. M. T. Noorman, Overview Techniques for Measuring Friction using Bench Tests and Fired Engines, SAE International, June 2000, pp. 1-11.

8. K. K. KUO. «Principles of Combustion ». Ed. John Wiley. New York

9. A. BOUKHALFA Combustion à l'étude de la structure scanner dans les flammes turbulentes prémélangées de type BUNSEN, thèse de doctorat d'état, université d'Orléans (1988).

10. R. MAAMRI, modélisation et expérimentation des moteurs à combustion fonctionnant avec différents carburants de substitution et mélanges, thèse de doctorat, université du Québec 